\title{
Dental Apps for Smartphones: New Way of Providing Services and Education
}

\author{
Isabella Marques Faria, Mariana Coutinho Sancas, Andréa Vaz Braga Pintor, \\ Laura Salignac Guimarães Primo*
}

Department of Pediatric Dentistry and Orthodontics, Universidade Federal do Rio de Janeiro, Rio de Janeiro, Brazil

Email: *lprimo@pobox.com

How to cite this paper: Faria, I. M., Sancas, M. C., Pintor, A. V. B., \& Primo, L. S. G. (2018). Dental Apps for Smartphones: New Way of Providing Services and Education. Creative Education, 9, 687-696. https://doi.org/10.4236/ce.2018.95050

Received: March 14, 2018

Accepted: April 20, 2018

Published: April 23, 2018

Copyright (c) 2018 by authors and Scientific Research Publishing Inc. This work is licensed under the Creative Commons Attribution International License (CC BY 4.0).

http://creativecommons.org/licenses/by/4.0/

\section{c) (i) Open Access}

\begin{abstract}
Objective: To review the literature about dental applications (DAPP) for smartphones (SP) and search/describe DAPP available in Portuguese, in 3 operating systems. Methods: Aiming the review, the terms "smartphones", "app" and "dentistry" were searched in the databases Pubmed, Virtual Health Library (BVS) and Google Scholar. Based on the review results, DAPP were searched for teaching and learning (TL), clinical practice (CP), patient orientation (PO) and professional update (PU), in Portuguese, in the Android, iOS and Windows systems. In 3 SP (iPhone 5 S with iOS 9.3.5; Samsung Galaxy A5 62016 with Android; Microsoft-RM-1109 with Windows Phone 8.1 Update2) the term "dentistry" was inserted in APP searches. Results: Forty-three papers were included in the review and 215 DAPP were selected: 120 on Android, 90 on iOS, and 5 on Windows. DAPP were classified according to the focus in: $\mathrm{CP}(\mathrm{n}=99) ; \mathrm{PO}(\mathrm{n}=6) ; \mathrm{CP} / \mathrm{PO}(\mathrm{n}=64) ; \mathrm{TL} / \mathrm{CP}(\mathrm{n}=6) ; \mathrm{TL}(\mathrm{n}=38)$; TL/CP/PO ( $n=1)$ And PU and TL $(n=1)$. The majority of the DAPP was not validated by any Dental institution (93.02\%) and was no cost way for users (81.86\%), although only 58.14 were updated. Conclusion: Most of the papers showed as main focus CP, TL and PO. The DAPP available in Portuguese for Dentistry were mostly developed for clinical practice, with a lack of those for patient orientation and teaching and learning. Future Dental APP should provide evidence-based, validated, updated data.
\end{abstract}

\section{Keywords}

Apps, Smartphone, Dentistry, Education, Clinical Practice

\section{Introduction}

Smartphones have been one of the success stories of the last decade (Boulos et 
al., 2011). They are mobile phones with an integrated computer capable of performing a wide variety of tasks, including downloading various applications that are not typically associated with a mobile phone (Franko, 2011). The development of mobile computing applications for smartphones represents an interesting and effective way to provide a new technological tool and reach the desired target audience (Tibes, Dias, \& Zem-Mascarenhas, 2014).

Therefore, with the development of mobile applications designed specifically for the medical and dental areas, healthcare professionals have been experiencing a new way of providing services and teaching (Khatoon, Hill \& Walmsley, 2015). The use of applications through mobile devices, can facilitate and expedite the communication with patients, access to patients' exams, contributing to the establishment of diagnosis and with the follow-up. In addition, mobile apps enabled the possibility of access to scientific literature and guidelines of clinical protocols in the palm of the hand (Souza et al., 2013). Within the health area, this has been one of the fastest growing categories with numerous potential benefits. Its development has created new opportunities to integrate mobile technology into daily clinical practice (Baheti \& Toshniwal, 2014).

There are few studies considering the use of apps for mobile phones on Dentistry, regarding clinical practice, patient orientation and teaching and learning process. Furthermore, an overview of the dental applications for smartphones available in Brazil has not been conducted yet. Therefore, the aim of this study was to review the literature about Dental applications (DAPP) for smartphones (SP) and search/describe those available in Portuguese, in 3 main operating systems.

\section{Methods}

\subsection{Review of the Literature}

Previously to the observational study, a prospective review of literature was performed aiming to know and understand the role of mobile applications for smartphones in Dentistry. The terms "smartphones", "app" and "dentistry" were searched in the database Pubmed using the search strategy (smartphone OR app) AND (dent ${ }^{*}$ ) NOT beta-amyloid precursor protein). The terms were also searched in Portuguese in Virtual Health Library (BVS) (aplicativos AND smartphones AND odontologia) and Google scholar ("aplicativos para smartphones em odontologia") databases. The articles published in English or Portuguese that considered the use of DAPP for the clinical practice, patient orientation and teaching and learning process were selected for reading. Thesis, dissertations, editorials and other types of publication that were not scientific articles or those in languages different from English or Portuguese were excluded.

\subsection{Observational Study}

Dental applications (DAPP) for smartphones (SP) targeted to teaching and learning $(\mathrm{TL})$, clinical practice $(\mathrm{CP})$, patient orientation $(\mathrm{PO})$ and professional 
update (PU), in Portuguese, were searched in the Android, iOS and Windows systems in Brazil. In three Smartphones (iPhone 5S with iOS 9.3.5; Samsung Galaxy A5 62016 with Android; Microsoft-RM-1109 with Windows Phone 8.1 Update 2) the term "dentistry" was inserted in APP searches. Applications that were not in Portuguese, games and those targeted to other issues that not dentistry were excluded. Portuguese was the only language included, since this is the official Brazilian language, clear for any Brazilian citizen.

Data extraction included the general characteristics of the selected DAPP: name, operative system, date of last update, cost, category and institutional validation. The data was tabulated in an Excel ${ }^{\circ}$ chart.

\section{Results}

The forty papers selected based on the inclusion and exclusion criteria, were published between 2010 and 2017, showing a growing interest in recent literature regarding the use of mobile applications in Dentistry. Clinical practice represented the area of greatest interest, followed by the areas of teaching and learning and patient orientation (Table 1).

After analyzing the information available in the surveyed operating systems, 215 applications were selected, according the inclusion and exclusion criteria. Out of these, 120 (55.81\%) were available on the iOS, 90 (41.86\%) on Android and $5(2.32 \%)$ on Windows. The majority of Dental applications did not have access costs (81.86\%). The applications related to the topic Clinical Practice represented the great majority of the applications, when compared to those associated with the other topics researched. Recognized dental institutions validated less than $10 \%$ of the Dental applications. Furthermore, just over half of the applications (58.14\%) were updated. The characteristics of the analyzed applications were described in Table 2.

\section{Discussion}

Smartphones and applications have contributed to the technological advancement in health care in recent years, influencing methods of research, access to information and communication between professionals and patients (Collado-Borrell et al., 2016). The data obtained in the review suggested that researchers were interested, mainly, in understanding the potential of using, developing and evaluating these new tools available for dentistry, especially those designed for the clinical activity (Dhuvad, Dhuvad, \& Kshirsagar, 2015; Tam \& Lee, 2016; Estai et al., 2016; Adams, 2016; Kalman, Chrapka, \& Joseph, 2016). The interest is relevant, since applications for Dentistry can facilitate the tasks related to information processing and communication, such as: registration of patient information, research in specific literature, discussion with colleagues and auxiliary professionals and communication with patients. (Souza et al., 2013; Sarode et al., 2016; Stein et al., 2016; Bullock et al., 2015; Hardyman et al., 2013).

Regarding the teaching and learning process, the authors highlighted the 
Table 1. Selected studies in chronological presentation and areas of interest.

\begin{tabular}{|c|c|}
\hline Author & Area of interest \\
\hline Alklayb et al., 2017 & Patient orientation \\
\hline Bohn et al., 2017 & Patient orientation \\
\hline Deshpande et al., 2017 & Teaching and learning \\
\hline Tam \& Li., 2016 & Clinical practice \\
\hline Madan Kumar et al., 2016 & Teaching and learning \\
\hline Al-Musawi et al., 2016 & Teaching and learning \\
\hline Sarode et al., 2016 & Clinical practice \\
\hline Stein et al., 2016 & Clinical practice \\
\hline Pulijala et al., 2016 & Patient orientation \\
\hline Estai et al., 2016 & Clinical practice \\
\hline Adams, 2016 & Clinical practice \\
\hline Petruzzi \& Benedittis., 2016 & Patient orientation \\
\hline Kalman et al., 2016 & Clinical practice \\
\hline Djemal \& Singh., 2016 & Clinical practice and patient orientation \\
\hline Estai et al., 2016 & Clinical practice \\
\hline Könings et al., 2016 & Teaching and learning \\
\hline Khatoon et al., 2015 & Teaching and learning \\
\hline Li et al., 2016 & Patient orientation \\
\hline Dhuvad et al., 2015 & Clinical practice \\
\hline Masika et al., 2015 & Teaching and learning \\
\hline Underwood et al., 2015 & Patient orientation \\
\hline Bullock et al., 2015 & Clinical practice \\
\hline Zotti et al., 2016 & Patient orientation \\
\hline Bullock \& Webb, 2015 & Teaching and learning \\
\hline Pinheiro et al., 2015 & Review \\
\hline Senthoor et al., 2014 & Clinical practice \\
\hline Rung et al., 2014 & Teaching and learning \\
\hline Baheti \& Toshniwal., 2014 & Teaching and learning and Clinical practice \\
\hline Lin et al., 2014 & Patient orientation and Clinical practice \\
\hline Keim, 2014 & Clinical practice \\
\hline O'Reilly et al., 2014 & Clinical practice \\
\hline Tibes et al., 2014 & Review \\
\hline Schulz et al., 2013 & Teaching and learning \\
\hline Mladenović et al., 2013 & Clinical practice \\
\hline Hardyman et al., 2013 & Clinical practice \\
\hline Figueiredo et al., 2013 & Clinical practice \\
\hline Souza et al., 2013 & Clinical practice \\
\hline Bahcall, 2012 & Clinical practice \\
\hline Pavan et al., 2012 & Clinical practice \\
\hline Richards, 2012 & Clinical practice \\
\hline
\end{tabular}


Table 2. Characteristics of the analyzed applications.

\begin{tabular}{|c|c|c|}
\hline Characteristics & $\mathbf{N}$ & Percentage \\
\hline \multicolumn{3}{|l|}{ Operating system } \\
\hline Android & 120 & $55.81 \%$ \\
\hline iOS & 90 & $41.86 \%$ \\
\hline Windows & 5 & $2.32 \%$ \\
\hline \multicolumn{3}{|l|}{ Cost } \\
\hline Yes & 37 & $17.20 \%$ \\
\hline No & 176 & $81.86 \%$ \\
\hline \multicolumn{3}{|l|}{ Categories } \\
\hline Clinical practice & 99 & $46.04 \%$ \\
\hline Teaching and learning & 38 & $17.67 \%$ \\
\hline Patient orientation & 6 & $2.79 \%$ \\
\hline $\begin{array}{l}\text { Patient orientation }+ \text { Clinical } \\
\text { practice }\end{array}$ & 64 & $29.76 \%$ \\
\hline $\begin{array}{c}\text { Clinical practice }+ \text { Teaching and } \\
\text { learning }\end{array}$ & 6 & $2.79 \%$ \\
\hline $\begin{array}{l}\text { Teaching and Learning + Clinical } \\
\text { practice + Patient orientation }\end{array}$ & 1 & $0.46 \%$ \\
\hline $\begin{array}{c}\text { Professional update }+ \text { Teaching and } \\
\text { learning }\end{array}$ & 1 & $0.46 \%$ \\
\hline \multicolumn{3}{|l|}{ Last updating (year) } \\
\hline 2016 & 125 & $58.14 \%$ \\
\hline 2015 & 44 & $20.47 \%$ \\
\hline 2014 & 24 & $11.16 \%$ \\
\hline 2013 & 9 & $4.19 \%$ \\
\hline 2012 & 6 & $2.79 \%$ \\
\hline 2011 & 1 & $0.46 \%$ \\
\hline 2010 & 1 & $0.46 \%$ \\
\hline \multicolumn{3}{|l|}{ Validation } \\
\hline Yes & 15 & $6.97 \%$ \\
\hline No & 200 & $93.02 \%$ \\
\hline
\end{tabular}

importance of using smartphone applications as a new tool available to facilitate learning (Rung et al., 2014). Mobile devices have become popular technologies not only for Internet access, which enables quick access to books and articles, but also for the possibility of downloading applications that can be used as pedagogical tools inside and outside the classrooms (Pinheiro et al., 2015). The use of mobile technology for educational purposes is known as mobile learning (m-learning) (Farias et al., 2015). The use of mobile applications offers: accessibility, mobility, continuous capability of data transmission, geolocation and multimedia capability (Pinheiro et al., 2015). Teaching and learning methods 
should be dynamic and in line with social needs and demands. The current generation of students was born and grew up surrounded by and involved with information technology, which permeates their social relations and in general their perception of the world (Schulz et al., 2013). Thus, the use of mobile learning is already a reality (Rung et al., 2014; Bullock et al., 2015). Information and communication technology has proved to be a critical component of teaching and learning in higher education and in the education of health professionals. Mobile devices can contribute significantly to a new way of educating in health (Deshpande, Chahande, \& Rathi, 2017).

Currently, smartphones and applications are accessible to most people (Al-Musawi et al., 2016), due to their fast popularization and lower acquisition costs, generating a society increasingly immersed in the context of mobile devices and permanently connected. However, this society could benefit even more from the use of oral health applications by the use of m-learning as an educational strategy targeted to the most vulnerable population providing knowledge about preventive actions and promoting oral health (Madan Kumar et al., 2016). Therefore, in view of the technological scenario that we are experiencing, mobile devices are seen as a great strategy to contribute to health education (Farias et al., 2015; Khatoon, Hill, \& Walmsley, 2015). Moreover, the articles that discussed the use of applications in relation to Patient Orientation concluded that the applications represent an important vehicle for information access (Pulijala et al., 2016) for selfcare in oral health (Petruzzi \& Benedittis, 2016; Li et al., 2016, Zotti et al., 2016). Thus, the use of applications can contribute to an upstream approach to oral health promotion, that is, it could minimize inequalities, facilitate access to information relevant to health and the creation of favorable environments for it. In Brazil, applications were developed to support the dental professionals who work in the Family Health Strategy Program. Through this system, it is possible to archive information regarding the oral health of patients who received home visits. These systems were recommended for the purpose of ensuring efficiency in home care, organization of data collected and patient orientation (Tibes, Dias, \& Zem Mascarenhas, 2014).

Applications for patient education have been developed to explain dental treatment. In this sense they can be an interesting method to reduce patient's anxiety, helping them to cope with the dental treatment. The effectiveness of an application in educating mothers about the importance of preventive dental care was also reported. The Internet and the use of smartphones have changed the way we live in the 21st century. The use of the Internet in the incorporation of new ideals is well known, however it must be remembered that it could also serve as a channel to improve the life of individuals and the society (Alklayb et al., 2017).

The present study presented relevant information about the applications available in Portuguese for Dentistry by the main operating systems used in smartphones in Brazil. It was observed that Clinical practice represented the 
main thematic focus and represented the largest number of applications identified. This observation brings light to a wide range of possibilities for the development of applications for oral health professionals and the support and guidance of patients. In addition, it was noted that most applications do not have validation by scientific institutions or commissions. Since applications are currently an important source of information, it becomes evident that application's developers should seek endorsement from recognized Dentistry references.

Regarding the applications available for Clinical practice and Patient orientation, it was observed that the main objective was to assist the professional and inform the patient. Within this group, many applications were related to dental health plans, which at the same time helped the patient to find a nearby clinic, to consult the accredited network, access to the virtual identification card to use in emergencies and assist the dentist in their clinical practice by facilitating patient access to the dental office.

The applications focused on the theme of Teaching and learning had as main purpose the communication between institutions/teachers and students. Such applications represent an important point in the advancement of information exchange in real time, but are still poor in the process of teaching and learning itself. From the pedagogical point of view, expanding access to content inside and outside the classroom and searching for information "in the palm of the hand" via applications could both enrich the discussion and stimulate students in the search for knowledge (Rung et al., 2014). We understand that the use of these new tools could immediately become a challenge for students and teachers, especially regarding the compatibility of contents. However, the role of teachers, as tutors, through the direction of critical thinking, dealing with real time information, could benefit students in the construction and retention of knowledge.

\section{Conclusion}

Dental applications research presented as main focus clinical practice, teaching and learning and patient orientation. The overview of the dental applications available in Portuguese for smartphones showed that the great majority was developed for clinical practice, with a lack of applications aimed at patient orientation and teaching and learning. Future Dental APP should provide evidence-based, validated, updated data.

\section{References}

Adams, B. W. (2016). Automation and Apps for Clinical Dental Biomechanics. Cranio, 34, 343-347. https://doi.org/10.1080/08869634.2015.1113689

Alklayb, S. A., Assery, M. K., Alqahtani, A., Alanazi, M., \& Pani, S. C. (2017). Comparison of the Effectiveness of a Mobile Phone-Based Education Program in Educating Mothers as Oral Health Providers in Two Regions of Saudi Arabia. Journal of International Society of Preventive \& Community Dentistry, 7, 110-115.

Al-Musawi, A., Al-Sane, M., \& Andersson, L. (2016). Smartphone App as an Aid in the 
Emergency Management of Avulsed Teeth. Dental Traumatology, 33, 13-18. https://doi.org/10.1111/edt.12298

Bahcall, J. (2012). Endodontic Diagnosis: There's an App for That! Dentistry Today, 31, 52-55.

Baheti, M. J., \& Toshniwal, N. (2014). Orthodontic Apps at Fingertips. Progress in Orthodontics, 15, 36. https://www.ncbi.nlm.nih.gov/pubmed/24950127 https://doi.org/10.1186/s40510-014-0036-y

Bohn, C. E., McQuistan, M. R., McKernan, S. C., \& Askelson, N. M. (2017). Preferences Related to the Use of Mobile Apps as Dental Patient Educational Aids: A Pilot Study. Journal of Prosthodontics, 1-6.

Boulos, M. N. K., Wheeler, S., Tavares, C., \& Jones, R. (2011). How Smartphones Are Changing the Face of Mobile and Participatory Healthcare: An Overview, with Example from eCAALYX. BioMedical Engineering Online, 24, 1-14.

https://www.ncbi.nlm.nih.gov/pmc/articles/PMC3080339/ https://doi.org/10.1186/1475-925X-10-24

Bullock, A., \& Webb, K. (2015).Technology in Postgraduate Medical Education: A Dynamic Influence on Learning? Postgraduate Medical Journal, 91, 646-650.

https://www.ncbi.nlm.nih.gov/pubmed/26341127

https://doi.org/10.1136/postgradmedj-2014-132809

Bullock, A., Dimond, R., Webb, K., Lovatt, J., Hardyman, W., \& Stacey, M. (2015). How a Mobile App Supports the Learning and Practice of Newly Qualified Doctors in the UK: An Intervention Study. BioMedCentral Medical Education, 15, 1-6. https://doi.org/10.1186/s12909-015-0356-8

Collado-Borrell, R., Escudero-Vilaplana, V., Ribed-Sánchez, A., Ibáñez-García, S., Herranz-Alonso, A., \& Sanjurjo-Sáez, M. (2016). Smartphone Applications for Cancer Patients; What We Know about Them? Farmacia Hospitalaria, 40, 25-35.

Deshpande, S., Chahande, J., \& Rathi, A. (2017). Mobile Learning App: A Novel Method to Teach Clinical Decision Making in Prosthodontics. Education for Health, 30, 31-34. https://doi.org/10.4103/1357-6283.210514

Dhuvad, J. M., Dhuvad, M. M., \& Kshirsagar, R. A. (2015). Have Smartphones Contributed in the Clinical Progress of Oral and Maxillofacial Surgery? Journal of Clinical \& Diagnostic Research, 9, 22-24. https://doi.org/10.7860/JCDR/2015/14466.6454

Djemal, S., \& Singh, P. (2016) Smartphones and Dental Trauma: The Current Availability of Apps for Managing Traumatic Dental Injuries. Dental Traumatology, 32, 52-57. Available from: https://www.ncbi.nlm.nih.gov/pubmed/26387767 https://doi.org/10.1111/edt.12217

Estai, M., Kanagasingam, Y., Huang, B., Checker, H., Steele, L., Kruger, E., \& Tennant, M. (2016). The Efficacy of Remote Screening for Dental Caries by Mid-Level Dental Providers Using a Mobile Teledentistry Model. Community Dentistry and Oral Epidemiology, 44, 435-441. https://doi.org/10.1111/cdoe.12232

Farias, A. B., Pereira, M., Souto, M., \& Alencar, R. (2015). Educação em saúde no Brasil: Uma revisão sobre aprendizagem móvel e desafios na promoção de saúde no Brasil. In Anais do XXI Workshop de informática na escola (pp. 26-30, 614-623). Maceió. https://doi.org/10.5753/cbie.wie.2015.614

Figueiredo, M. C., Jardim, L. E., Barone, D. A. C., \& Wink, G. L. (2013). A utilização da computação móvel na armazenagem de dados de pacientes em atendimentos domiciliares de saúde. ConScientiae Saúde, 12, 621-630.

Franko, O. I. (2011). Smartphone Apps for Orthopaedic Surgeons. Clinical Orthopaedics and Related Research, 469, 2042-2048. https://doi.org/10.1007/s11999-011-1904-0 
https://www.ncbi.nlm.nih.gov/pubmed/21547414

Hardyman, W., Bullock, A., Brown, A., Carter-Ingram, S., \& Stacey, M. (2013). Mobile Technology Supporting Trainee Doctors' Workplace Learning and Patient Care: An Evaluation. BMC Medical Education, 13, 6. https://doi.org/10.1186/1472-6920-13-6 https://www.ncbi.nlm.nih.gov/pubmed/26341127

Kalman, L., Chrapka, J., \& Joseph, Y. (2016). Digitizing the Facebow: A Clinician/Technician Communication Tool. International Journal of Prosthodontics, 29, 35-37. https://doi.org/10.11607/ijp.4748

Keim, R. G. (2014). Practicing by Smartphone. Journal of Clinical Orthodontics, 48, 145-146.

Khatoon, B., Hill, K. B., \& Walmsley, A. D. (2015). Instant Messaging in Dental Education. Journal of Dental Education, 79, 1471-1478.

Könings, K. D., van Berlo, J., Koopmans, R., Hoogland, H., Spanjers, I. A., ten Haaf, J. A., van der Vleuten, C. P., \& van Merriënboer, J. J. (2016). Using a Smartphone App and Coaching Group Sessions to Promote Residents' Reflection in the Workplace. Academic Medicine, 91, 365-370. https://www.ncbi.nlm.nih.gov/pubmed/26556297 https://doi.org/10.1097/ACM.0000000000000989

Li, X., Xu, Z. R., Tang, N., Ye, C., Zhu, X. L., Zhou, T., \& Zhao, Zh. (2016). Effect of Intervention using a Messaging App on Compliance and Duration of Treatment in Orthodontic Patients. Clinical Oral Investigations, 20, 1849-1859.

https://doi.org/10.1007/s00784-015-1662-6

Lin, C. Y., Peng, K. L., Chen, J., Tsai, J. Y., Tseng, Y. C., Yang, J. R. et al. (2014). Improvements in Dental Care using a New Mobile App with Cloud Services. Journal of the Formosan Medical Association, 113, 742-749.

https://doi.org/10.1016/j.jfma.2014.02.009

Madan Kumar, P. D., Mohandoss, A. A., Walls, T., Rooban, T., \& Vernon, L. T. (2016). Using Smartphone Video "Selfies" to Monitor Change in Toothbrushing Behavior after a Brief Intervention: A Pilot Study. Indian Journal of Dental Research, 27, 268-277. https://doi.org/10.4103/0970-9290.186241

Masika, M. M., Omondi, G. B., Natembeya, D. S., Mugane, E. M., Bosire, K. O., \& Kibwage, I. O. (2015). Use of Mobile Learning Technology among Final Year Medical Students in Kenya. Pan African Medical Journal, 21, 127.

https://www.ncbi.nlm.nih.gov/pubmed/26327964 https://doi.org/10.11604/pamj.2015.21.127.6185

Mladenović, D., Tosić, G., Zivković, D., Djindjić, N., Mladenović, L., Mladenović, S. et al. (2013). Telemedicine Consulting in the Patient Preparation and Planning of Prosthetic Tooth Replacement. Vojnosanitetski Pregled, 70, 866-870.

O’Reilly, M. K., Nason, G. J., Liddy, S., Fitzgerald, C. W., Kelly, M. E., \& Shields, C. (2014). DOCSS: Doctors On-Call Smartphone Study. Irish Journal of Medical Science, 183, 573-577. https://doi.org/10.1007/s11845-013-1053-4

Pavan, K. M., Praveen, K. N., \& Vasu Murthy, S. (2012). Model Analysis on a Smartphone. Journal of Clinical Orthodontics, 46, 356-358.

Petruzzi, M., \& De Benedittis, M. (2016). Whats App: A Telemedicine Platform for Facilitating Remote Oral Medicine Consultation and Improving Clinical Examinations. Oral Surgery, Oral Medicine, Oral Pathology and Oral Radiology, 121, 248-254.

https://doi.org/10.1016/j.oooo.2015.11.005

Pinheiro, C. B. V., Carvalho, J. M., \& Carvalho, F. L. Q. (2015). Tecnologias em educação e saúde: Papel na promoção de saúde bucal. Seminário de Tecnologias Aplicadas a Educação e Saúde. http://www.revistas.uneb.br/index.php/staes/article/view/1616/1092 
Pulijala, Y., Ma, M., Ju, X., Benington, P., \& Ayoub, A. (2016). Efficacy of Three-Dimensional Visualization in Mobile Apps for Patient Education Regarding Orthognathic Surgery. International Journal of Oral and Maxillofacial Surgery, 45, 1081-1085. https://doi.org/10.1016/j.ijom.2016.04.002

Richards, D. (2012). SDCEP Dental Prescribing App. Evidence Based Dentistry, 13, 61-62. https://doi.org/10.1038/sj.ebd.6400867

Rung, A., Warnke, F., \& Mattheos, N. (2014). Investigating the Use of Smartphones for Learning Purposes by Australian Dental Students. JMIR mHealth and uHealth, 2, e20. https://www.ncbi.nlm.nih.gov/pubmed/25099261 https://doi.org/10.2196/mhealth.3120

Sarode, G. S., Sarode, S. C., \& Patil, S. (2016). Messenger Services on Smartphone: Changing Trends of Communication in Dental Practice. The Journal of Contemporary Dental Practice, 17, 267-269. https://www.ncbi.nlm.nih.gov/pubmed/27340158 https://doi.org/10.5005/jp-journals-10024-1839

Schulz, P., Sagheb, K., Affeldt, H., Klumpp, H., Taylor, K., Walter, C., \& Al-Nawas, B. (2013). Acceptance of E-Learning Devices by Dental Students. Medicine 2.0, 2, e6. https://www.ncbi.nlm.nih.gov/pmc/articles/PMC4084775/ https://doi.org/10.2196/med20.2767

Senthoor Pandian, S., Srinivasan, P., \& Mohan, S. (2014). The Maxillofacial Surgeon's March towards a Smarter Future-Smartphones. Journal of Maxillofacialand Oral Surgery, 13, 355-358. https://doi.org/10.1007/s12663-013-0497-4

Souza, R. C., Alves, L. A. C., Haddad, A. E., Macedo, M. C. S., \& Ciamponi, A. L. (2013). Processo de criação de um aplicativo móvel na área de odontologia para pacientes com necessidades especiais. Revista da $A B N O, 13,58-61$.

Stein, C. D., Xiao, X., Schleyer, T. K., Hochheiser, H., \& Thyvalikakath, T. P. (2016). A Prototype Mobile Application for Triaging Dental Emergencies. Journal of the American Dental Association, 16, 1-10.

Tam, W. K., \& Lee, H. J. (2016). Accurate Shade Image Matching by Using a Smartphone Camera. Journal of Prosthodontic Research, 61, 168-176. https://doi.org/10.1016/j.jpor.2016.07.004

Tibes, C. M. S., Dias, J. D., \& Zem-Mascarenhas, S. H. (2014). Aplicativos móveis desenvolvidos para a área da saúde no Brasil. Revista Mineira de Enfermagem, 18, 471-478.

Underwood, B., Birdsall, J., \& Kay, E. (2015). The Use of a Mobile App to Motivate Evidence-Based Oral Hygiene Behaviour. British Dental Journal, 219, E2. https://www.ncbi.nlm.nih.gov/pubmed/26315196 https://doi.org/10.1038/sj.bdj.2015.660

Zotti, F., Dalessandri, D., Salgarello, S., Piancino, M., Bonetti, S., Visconti, L., \& Paganelli, C. (2016). Usefulness of an App in Improving Oral Hygiene Compliance in Adolescent Orthodontic Patients. The Angle Orthodontist, 1, 101-107.

https://doi.org/10.2319/010915-19.1 